\title{
Examining the Correlation between Smartphone Addiction and Leisure Boredom Perception in Ice Hockey Players
}

\author{
Muharrem Alparslan Kurudirek (Corresponding author) \\ Faculty of Sports Sciences, Ataturk University, Erzurum, Turkey \\ E-mail: akurudirek@atauni.edu.tr
}

Muhammet Irfan Kurudirek

School of Physical Education \& Sports, Artvin Coruh University, Artvin, Turkey

E-mail: irfankurudirek@artvin.edu.tr

Received: November 5, $2021 \quad$ Accepted: December 3, 2021

Published: December 31, 2021

doi:10.5296/jei.v7i3.19147 URL: https://doi.org/10.5296/jei.v7i3.19147

\begin{abstract}
The purpose of this study was to determine smartphone addiction and leisure boredom perception levels in ice hockey players in Turkey, examine them in terms of age, sex and educational level, and investigate the correlation between smartphone addiction and leisure boredom perception. The population of the study consisted of athletes actively playing in ice hockey leagues in Turkey. The sample group comprised a total of 85 athletes (51 males and 34 females) who were selected randomly from the population and were voluntary to participate in the study. In the study, a questionnaire with three sections was used as the data collection tool. The first section of the questionnaire was a personal information form prepared by the researcher to determine the age, sex, and educational background of the participants. In the second section of the questionnaire, the Smartphone Addiction Scale-Short Version (SAS-SV) was used for measuring the smartphone addiction levels of the participants. In the third and last section of the questionnaire, the Leisure Boredom Scale (LBS) was used for determining the leisure boredom perception of the participants. In the data assessment, the SPSS 26 package software was used. After transferring the data collected via the data collection tool into the electronic environment, the normality was first tested and then non-parametric analyses were performed upon detecting that the data were
\end{abstract}




\section{Macrothink}

not normally distributed. When examining the findings of the study, it was observed that most of the participants were male, had high school education and below and were aged 15 to 17 years. In addition, the mean scores of the participants were higher in the Leisure Boredom Scale Boredom Subscale, moderate in the Leisure Boredom Scale Satisfaction Subscale and higher in the Smartphone Addiction Scale-Short Version. It was determined that the female participants had higher mean ranks in the Leisure Boredom Scale Boredom Subscale compared to the male participants at a statistically significant level. When examining the correlation between the smartphone addiction and leisure boredom perception of the participants, it was also observed that there was a statistically significant, positive, and weak correlation between the smartphone addiction and the boredom subscale of the leisure boredom perception.

Keywords: Ice hockey, Leisure, Smartphone addiction

\section{Introduction}

Smartphones are defined as mobile phones that have a touch-operated use and a specific systematics connecting to social networks and general networks and have and can carry out most properties and operations of laptops and desktops (Muharremoğlu, 2020). Together with today's rapidly progressing mobile technology, smartphones have begun to be essential for human life. Smartphones, which incorporate properties simplifying the working and life conditions of humans, have come into prominence with number of users and usage opportunities in recent years (Levent, 2020).

The studies have demonstrated that the smartphone use rate is increasing every year (Ada \& Tatl1, 2012; Yıldırım \& Kişioğlu, 2018). Based on the world countries, the smartphone use rate of Turkey is 59\% and Turkey is ranked as twelfth with this rate (Yalçın et al., 2017). The Turkish Statistical Institute (TUIK, 2020) reported that the internet use rate was $79.0 \%$ among people aged 16 to 74 years. On the other hand, this rate was $75.2 \%$ in 2019 . According to the 2019 results of the Survey on Information and Communication Technology Usage in Households, the computer and internet usage rate is the highest among people aged 25 to 34 years (TUIK, 2019). According to a report published by We Are Social (2020) research company, 62 million of the Turkish population use the internet. The report states that the average internet use of the users is 7.5 hours daily and $94 \%$ of the population using the internet access it via smartphones. When examining the literature knowledge, it is seen that the common age range in the internet, smartphone and computer use is the emerging adulthood.

In the study conducted by "Hitwise Mobile" it was found that the categories most searched by connecting to the internet via mobile devices were "foods and beverages (72\%), health $(68 \%)$, sports $(68 \%)$, news and media (64\%), automotive $(62 \%)$, retail $(56 \%)$, travel $(52 \%)$, real estate (48\%), entertainment (42\%) and banking (39\%)" (Gedik, 2020). From this point of view, it can be asserted that people doing sports also follow the developments and news related to sports via mobile devices.

It is of prime importance to evaluate leisure well and prevent boredom perception in order to 
create a positive value in the lives of people. Otherwise, the period of leisure will prelude to a great danger instead of being useful for community health. Smart use of leisure is accepted to be a product of civilization and education (Russel, 2020).

\subsection{Smartphone Addiction}

Smartphone is a mobile phone which has properties such as accessing the internet, downloading applications and offers a personal computer functionality (Tüzüntürk, 2017).

Smartphone Addiction does not have a clear definition like a game, social media or internet addiction (Fidan, 2016). Indeed, in some studies it is called as "problematic use of smartphones", while in some studies it is also called as "smartphone addiction" (Martinotti et al., 2011)

Smartphones make great contributions to our lives. They give all opportunities offered by a computer. They have contributed to communication to be fast and diverse in health, education, commerce and many more areas. Mobile phones which conduct many precious functions in a short time and facilitate the functions lead to problems besides advantages. The individual can use social media more effectively with smartphones. However, while he/she becomes successful in socializing in the virtual world, he/she gets estranged from his/her family without establishing communication and isolates himself/herself from the present life (Şata et al., 2016).

Possible physical and mental problems to be caused by excessive use of smartphones can be listed as follows:

- Having physical problems such as headache and eye pain due to excessive use of smartphones,

- Minimizing activities like meeting friends in real environments due to applications in smartphones and consequently getting lonely,

- Being unable to adapt to the normal life due to constantly dealing with the smartphone,

- Having a risk of being in illegal environments due to relationships established in unreal environments via smartphones (Ünal, 2015).

\subsection{Leisure Boredom Perception}

Leisure boredom perception has been studied by scientists over the years. Recently it has begun to be examined under concepts such as monotony and uniformity which emerge when we deal with any work or occupation too much. This concept was included in different disciplines such as philosophy (Calhoun, 2011), psychology (Vodaservenovich, 2003), sociology (Conrad, 1997), education (Belton and Priyadharshini, 2007; Mann and Robinson, 2009), and anthropology (Musharbash, 2007) in the 1900s.

The research group consisted of adolescents and young people. When the literature is examined, it is seen that there are studies on the relationship between smartphone addiction and depression and anxiety disorder (Boumosleh, 2017). Iso-Ahola and Weissinger (1990) 
theoretically define the leisure boredom perception by associating with two contradictory situations, because leisure behaviors are at an optimal level when people feel that they have an accurate amount of time for leisure activities (not related with quantity). These situations are having too much time and having too few things to do. It is stressed that these two situations are interrelated and affect one another. Leisure boredom creates a perception reflecting a negative mood and low involvement which are encountered in people depending on present conditions and arise from conflicts. In order for leisure to be psychologically rewarding, it is necessary to activate these factors in the best manner. Haller et al. (2013) suggest that boredom perception, which is defined as a negative emotion, emerges because of continuity of monotonous activities or lack of stimulation and experiences containing no difficulty. Emergence of negative impacts because of increasing leisure is acceptable for some groups.

\section{Method}

The purpose of the study was to determine smartphone addiction and leisure boredom perception levels in ice hockey athletes in Turkey, examine them in terms of age, sex and educational level, and investigate the correlation between smartphone addiction and leisure boredom perception.

\subsection{Population and Sample of the Study}

The population of the study consisted of people actively playing in ice hockey leagues in Turkey. The sample group comprised a total of 85 athletes, (51 males and 34 females) who were selected from the population randomly and were voluntary to take part in the study.

\subsection{Data Collection Tools}

In the study, a questionnaire with three sections was used as the data collection tool. The first section of the questionnaire was a personal information form prepared by the researcher to determine the age, sex, and educational background of the participants. In the second section of the questionnaire, the Smartphone Addiction Scale-Short Version (SAS-SV), which was developed by Kwon et al., in 2013 and was adapted into Turkish by Noyan et al. (2015), was used for measuring the smartphone addiction levels of the participants. The scale has 10 items and one subscale. The Cronbach's alpha coefficient of the 6-point likert scale was found to be .867 . In the third and last section of the questionnaire, the Leisure Boredom Scale (LBS), which was developed by Iso-Ahola and Weissinger (1990) and was adapted into Turkish by Kara et al. (2014), was used for determining the leisure boredom perception of the participants. This 5-point likert scale has two subscales (boredom and satisfaction) and 10 items.

\subsection{Statistical Analysis}

In the data assessment, the SPSS 26 package software was used. After transferring the data, collected via the data collection tool, into the electronic environment, the normality was first tested and then non-parametric analyses were performed upon detecting that the data were not normally distributed. Accordingly, descriptive statistics for the determination of the 


\section{Macrothink}

Journal of Educational Issues

ISSN 2377-2263

2021, Vol. 7, No. 3, Special Issue

demographic characteristics of the participants, Mann-Whitney $U$ for the comparison of the LBS and SAS-SV averages in binary groups such as gender and education level, Kruskal Wallis $\mathrm{H}$ for the comparison of age groups, Spearman correlation for the determination of the relationship between LBS and SAS-SV test was applied.

\section{Results}

Table 1. Information about demographic variables of the participants

\begin{tabular}{|l|l|l|l|}
\hline \multirow{3}{*}{ Gender } & & $\mathrm{n}$ & $\%$ \\
\hline \multirow{3}{*}{ Educational background } & Male & 51 & 60 \\
\cline { 2 - 4 } & Female & 34 & 40 \\
\hline \multirow{3}{*}{ Age } & High school and below & 70 & 82.4 \\
\cline { 2 - 5 } & Associate degree and above & 15 & 17.6 \\
\hline \multirow{2}{*}{ Total } & $15-17$ & 49 & 57.6 \\
\cline { 2 - 5 } & $18-20$ & 20 & 23.5 \\
\cline { 2 - 5 } & $21+$ & 16 & 18.8 \\
\hline
\end{tabular}

When examining the table, it was observed that most of the participants were male, had high school education and below and were aged 15 to 17 years.

Table 2. The Smartphone Addiction Scale-Short Version (SAS-SV) and Leisure Boredom Scale (LBS) mean scores of the participants

\begin{tabular}{|l|l|l|l|l|l|}
\hline \multicolumn{2}{|l|}{} & N & Min & Max & $\mathbf{X} \pm$ SD \\
\hline \multirow{2}{*}{ LBS } & LBS Boredom & \multirow{2}{*}{85} & 1 & 5 & $3.83 \pm .696$ \\
\cline { 2 - 6 } & LBS Satisfaction & & & 5 & $3.08 \pm .716$ \\
\hline \multirow{2}{*}{ SAS-SV } & 85 & 1 & 6 & $4.60 \pm 1.109$ \\
\hline
\end{tabular}

When examining the table, it was observed that the mean scores of the participants were higher in the Leisure Boredom Scale Boredom Subscale, moderate in the Leisure Boredom Scale Satisfaction Subscale, and higher in the Smartphone Addiction Scale-Short Version. 
Table 3. Comparison of the Smartphone Addiction Scale-Short Version (SAS-SV) and Leisure Boredom Scale (LBS) mean scores of the participants according to their gender

\begin{tabular}{|c|c|c|c|c|c|c|c|}
\hline Factor & Variable & $\mathbf{N}$ & Mean Rank & Sum of Ranks & $\mathbf{U}$ & $\mathbf{Z}$ & $\mathbf{P}$ \\
\hline \multirow{2}{*}{ LBS Boredom } & Male & 51 & 36.88 & 1881 & \multirow{2}{*}{555} & \multirow{2}{*}{-2.813} & \multirow{2}{*}{$.005^{*}$} \\
\hline & Female & 34 & 52.18 & 1774 & & & \\
\hline \multirow{2}{*}{ LBS Satisfaction } & Male & 51 & 45.12 & 2301 & \multirow{2}{*}{759} & \multirow{2}{*}{-.975} & \multirow{2}{*}{.330} \\
\hline & Female & 34 & 39.82 & 1354 & & & \\
\hline \multirow{2}{*}{ SAS-SV } & Male & 51 & 39.39 & 2009 & \multirow{2}{*}{683} & \multirow{2}{*}{-1.653} & \multirow{2}{*}{.098} \\
\hline & Female & 34 & 48.41 & 1646 & & & \\
\hline
\end{tabular}

Based on the table, it was determined that there was a statistically significant difference between the groups in the LBS Boredom Subscale according to the gender of the participants. Accordingly, the female participants had higher mean ranks compared to the male participants at a statistically significant level. On the other hand, there was no statistically significant difference between the groups in terms of the Leisure Boredom Scale Satisfaction Subscale and the Smartphone Addiction Scale-Short Version mean ranks according to the gender of the participants.

Table 4. Comparison of the Smartphone Addiction Scale-Short Version (SAS-SV) and Leisure Boredom Scale (LBS) mean scores of the participants according to their educational level

\begin{tabular}{|c|c|c|c|c|c|c|c|}
\hline Factor & Variable & $\mathbf{N}$ & Mean Rank & Sum of Ranks & $\mathbf{U}$ & $\mathbf{Z}$ & $\mathbf{P}$ \\
\hline \multirow{2}{*}{ LBS Boredom } & High School and below & & 70 & 41.25 & \multirow{2}{*}{403.5} & \multirow{2}{*}{-1.408} & \multirow{2}{*}{.159} \\
\hline & Associate Degree and above & & 15 & 51.1 & & & \\
\hline \multirow{2}{*}{ LBS Satisfaction } & High School and below & & 70 & 44.24 & \multirow{2}{*}{438} & \multirow{2}{*}{-1.009} & \multirow{2}{*}{.313} \\
\hline & Associate Degree and above & & 15 & 37.20 & & & \\
\hline \multirow{2}{*}{ SAS-SV } & High School and below & & 70 & 42 & \multirow{2}{*}{455} & \multirow{2}{*}{-.808} & \multirow{2}{*}{.419} \\
\hline & Associate Degree and above & & 15 & 47.67 & & & \\
\hline
\end{tabular}

When examining the table, it was determined that there was no statistically significant difference between the groups in the Smartphone Addiction Scale-Short Version and the Leisure Boredom Scale Boredom and Satisfaction subscales according to the educational background of the participants. 


\section{Macrothink}

Table 5. Comparison of the Smartphone Addiction Scale-Short Version (SAS-SV) and Leisure Boredom Scale (LBS) mean scores of the participants according to their age groups

\begin{tabular}{|c|c|c|c|c|c|c|c|}
\hline Factor & Variable & $\mathbf{N}$ & Mean Rank & sd & $X^{2}$ & p & Difference \\
\hline \multirow{3}{*}{ LBS Boredom } & $15-17$ & 49 & 43.87 & \multirow{3}{*}{2} & \multirow{3}{*}{4.034} & \multirow{3}{*}{.133} & \multirow{3}{*}{-} \\
\hline & $18-20$ & 20 & 34.6 & & & & \\
\hline & $21+$ & 16 & 50.84 & & & & \\
\hline \multirow{3}{*}{ LBS Satisfaction } & $15-17$ & 49 & 47.4 & \multirow{3}{*}{2} & \multirow{3}{*}{3.777} & \multirow{3}{*}{.151} & \multirow{3}{*}{-} \\
\hline & $18-20$ & 20 & 36.15 & & & & \\
\hline & $21+$ & 16 & 38.09 & & & & \\
\hline \multirow{3}{*}{ SAS-SV } & $15-17$ & 49 & 40.46 & \multirow{3}{*}{2} & \multirow{3}{*}{1.575} & \multirow{3}{*}{.455} & \multirow{3}{*}{-} \\
\hline & $18-20$ & 20 & 44.3 & & & & \\
\hline & $21+$ & 16 & 49.16 & & & & \\
\hline
\end{tabular}

When examining the table, it was determined that there was no statistically significant difference between the groups in the Smartphone Addiction Scale-Short Version and the Leisure Boredom Scale Boredom and Satisfaction subscales according to the age groups of the participants.

Table 6. The Correlation between the Smartphone Addiction and Leisure Boredom Perception of the participants according to their age groups

\begin{tabular}{|l|l|l|l|l|l|}
\hline \multirow{2}{*}{} & \multicolumn{4}{|c|}{ Leisure Boredom Perception } \\
\cline { 2 - 6 } & \multicolumn{3}{|c|}{ Boredom } & \multicolumn{2}{c|}{ Satisfaction } \\
\cline { 2 - 6 } & $\mathrm{r}$ & $\mathrm{p}$ & $\mathrm{r}$ & $\mathrm{p}$ \\
\hline Smartphone Addiction & $.242 *$ & .026 & .132 & .229 \\
\hline
\end{tabular}

Note. ${ }^{*} \mathrm{p}<0.05$.

When examining the correlation between the smartphone addiction and leisure boredom perception of the participants based on the table, it was observed that there was a statistically significant, positive and weak correlation between the smartphone addiction and the Boredom Subscale of leisure boredom perception.

\section{Discussion}

In this section, the findings obtained from the study conducted to determine the correlation 
between smartphone addiction and leisure boredom perception in ice hockey athletes were discussed in the light of the studies in the relevant literature and were tried to be interpreted.

Examining the table including information about demographic variables of the participants, it was observed that most of the participants were male, had high school education and below, and were aged 15 to 17 years. Most of the national leagues in the activity calendar of Turkish ice hockey federation contain the age category of 15-17 (TBHF, 2021).

When examining the table concerning the SAS-SV and LBS mean scores of the participants, it was observed that the mean scores of the participants were higher in the Leisure Boredom Scale Boredom Subscale, moderate in the Leisure Boredom Scale Satisfaction Subscale, and higher in the Smartphone Addiction Scale-Short Version.

When examining the table comparing the Smartphone Addiction Scale-Short Version (SAS-SV) and Leisure Boredom Scale (LBS) mean scores of the participants according to their gender, it was observed that the female athletes had statistically higher mean ranks compared to the male athletes. This result is compatible with the results obtained from the study entitled "Smartphone Addiction in Adults" conducted by (K1lc1, 2021) with 370 people aged 18 to 30 years and the results obtained from the study entitled "Smartphone Addiction" conducted by Tarcan (2021) with 715 high school students. Additionally, in the study on smartphone addiction conducted by Y1lmaz et al., in Turkey it was indicated that the mean scores and addiction rate of the women were higher than those of the men (Y1lmaz, Sar and Civan, 2015). Evaluating specific to ice hockey sports, it is possible to interpret that higher number of practices and games in male teams compared to the number of practices and games in female teams causes more leisure for female athletes.

When examining the table comparing the Smartphone Addiction Scale-Short Version (SAS-SV) and the Leisure Boredom Scale (LBS) mean scores of the participants according to their educational level, it was determined that there was no statistically significant difference between the groups in the Smartphone Addiction Scale-Short Version and the Leisure Boredom Scale Boredom and Satisfaction subscales according to the educational background of the participants. This result is compatible with the study conducted by Minaz et al. (2017) in which they determined that there was no statistically significant difference in the smartphone use level according to the sex and educational level of the university students.

When examining the table comparing the SAS-SV and the LBS mean scores of the participants according to their age group, it was determined that there was no statistically significant difference between the groups in the Smartphone Addiction Scale-Short Version and the Leisure Boredom Scale Boredom and Satisfaction subscales according to the age groups of the participants.

Examining the table demonstrating the correlation between the smartphone addiction and leisure boredom perception of the participants according to their age groups, it was determined that as the leisure boredom level increased, the smartphone addiction increased. The whole sports industry has been affected negatively due to Covid-19 virus which has affected the whole world especially since the late 2019 and nearly all international and 
national organizations have been canceled in the age category comprising the population of the study. Increase in the smartphone addiction and leisure boredom levels can be explained with the cancellation of competitions and practices in the 2019-2020 and 2020-2021 seasons and sustainment of training processes online by young athletes.

As a consequence, it is recommended to carry out curricula starting from families in secondary and high school periods and provide intense and quality education to children and adolescents concerning smartphone addiction in family and schools in order to remove the negative impacts of smartphones on children and adolescents.

Also online training and development studies can be arranged for students and distance practice methods can be developed by relevant teams, clubs and federations.

The study is expected to set an example for other sports branches.

\section{References}

Ada, S., \& Tatlı, H. (2012). Akıllı telefon kullanımını etkileyen faktörler üzerine bir Araştırma. Akademik Bilişim Bildirisi.

Belton, T., \& Priyadharshini E. (2007). Boredom and schooling: A cross-disciplinary exploration. Cambridge Journal of Education, 37(4), 579-595. https://doi.org/10.1080/03057 640701706227

Calhoun, C. (2011). Living with boredom. Sophia, 50(2), 269-279. https://doi.org/10.1007/ s11841-011-0239-3

Conrad, P. (1997). It's boring: Notes on the meanings of boredom in everyday life. Qualitative Sociology, 20(4), 465-475. https://doi.org/10.1023/A:1024747820595

Fidan, H. (2016). Mobil Bağımlılık Ơlçeği’nin geliştirilmesi ve geçerliliği: Bileşenler modeli yaklaşımı. The Turkısh Journal on Addictıons, 3(3), 433-469. https://doi.org/10.15805/ Addicta.2016.3.0118

Gedik, Y. (2020). Mobil Pazarlama: Teorik Bir Çerçeve. Uluslararası Bilimsel Araștırmalar Dergisi, 5(3), 275-289. Retrieved from https://dergipark.org.tr/tr/pub/isrjournal/issue/57495/ 765948

Haller, M., Hadler, M., \& Kaup, G. (2013). Leisure time in modern societies: A new source of boredom and stress. Social Indicators Research, 111(2), 403-434. https://doi.org/10.1007/ s11205-012-0023-y

Iso-Ahola, S. E., \& Weissinger, E. (1990). Perceptions of boredom in leisure: Conceptualization, reliability and validity of the Leisure Boredom Scale. Journal of Leisure Research, 22(1), 1-17. https://doi.org/10.1080/00222216.1990.11969811

Kılc1, Ö. (2021). Beliren yetişkinlerde akıllı telefon bağımlılık düzeyi ile iletişim becerisi arasındaki ilişki (Master's thesis, Çağ Üniversitesi Sosyal Bilimler Enstitüsü).

Levent, A. (2020). Universite Ö̈rencilerinde Akıllı Telefon Bağmlılı̆̆ Ve Iletișsim Becerileri 
Arasındaki Ilișkinin Incelenmesi (Yüksek lisans tezi, Istanbul Gelişim Universitesi Lisansüstü Eğitim Enstitüsü, Psikoloji Anabilim Dalı, Istanbul).

Mann, S., \& Robinson, A. (2009). Boredom in the lecture theatre: An investigation into the contributors, moderators and outcomes of boredom amongst university students. British Educational Research Journal, 35(2), 243-258. https://doi.org/10.1080/01411920802042911

Martinotti, G., Corrado, V., Thine, D., Nicola, M., Bria, P., Conte, G., .. Torre, G. (2011). Problematic mobile phone use in adolescence: A cross-sectional study. Journal of Public Health, 19, 545-551. https://doi.org/10.1007/s10389-011-0422-6

Matar Boumosleh, J., \& Jaalouk, D. (2017). Depression, anxiety, and smartphone addiction in university students - A cross sectional study. PloS One, 12(8), e0182239. https://doi.org/ 10.1371/journal.pone.0182239

Mehmet, Ş. A. T. A., Çelik, İ., Ertürk, Z., \& Taş, U. E. (2016). Akıllı telefon bağımlılı̆̆ ölçeği'nin (ATBÖ) Türk lise öğrencileri için uyarlama çalışması. Journal of Measurement and Evaluation in Education and Psychology, 7(1), 156-169. https://doi.org/10.21031/ epod.95432

Minaz, A., \& Bozkurt, Ç. (2017). Universite Öğrencilerinin Akıllı Telefon Bağımlılık Düzeylerinin Ve Kullanım Amaçlarının Farklı Değişkenler Açısından Incelemesi. Mehmet Akif Ersoy Universitesi Sosyal Bilimler Enstitüsü Dergisi, 9(21), 268-286. https://doi.org/ 10.20875/makusobed.306903

Muharremoğlu, D. Z. (2020). Akıllı Telefon Bağmlılı̆̆ Envanteri-Kısa Formu'nun Türkçe'ye Uyarlanması ve Ankara'nın Pursaklar Ilçesi'ndeki Liselerde Oğrenim Gören 10. Sinıf Ö̆rencilerinin Akıllı Telefon Kullanma Ve Bağmlılık Durumu (Tıpta Uzmanlık Tezi, Hacettepe Universitesi, Halk Sağlı̆̆ı Anabilim Dalı, Ankara).

Musharbash, Y. (2007). Boredom, time, and modernity: An example from aboriginal Australia. American Anthropologist, 109(2), 307-317. https://doi.org/10.1525/aa.2007.109.2.307

Russell, B. (2020). Aylaklığa övgü(Çev. Mete Ergin). Istanbul: Cem Yayınevi.

Tarcan, N. (2021). Akıllı telefon kullanımı ve baglanma arasındaki ilișkinin incelenmesi (Üsküdar Üniversitesi, Sosyal Bilimler Enstitüsü, Yüksek Lisans Tezi).

TBHF. (2021). Bilgi Bankast. Retrieved from http://bilgibankasi.tbhf.org.tr/Ligler?id=1023

TUIK (Türkiye İstatistik Kurumu). (2019). Hane halkı Bilişim Teknolojileri Kullanımı Araştırmast.

TUIK (Türkiye İstatistik Kurumu). (2020). Retrieved from https://data.tuik.gov.tr/Bulten/ Index? $p=$ Hanehalki-Bilisim-Teknolojileri-(BT)-Kullanim-Arastirmasi-2020-33679

Tüzüntürk, S. (2017). Uyum analizi kullanarak Y kuşağı akıllı telefon kullanıcılarının tüketici davranışlarının anlaşılması: Bursa örneği. Marmara Universitesi İktisadi Ve İdari Bilimler Dergisi, 39(1), 257-280. https://doi.org/10.14780/Muiibd.329937 


\section{Macrothink}

Unal, M. (2015). Ankara Yıldırım Beyazıt Universitesi Tıp Fakuiltesi Ö̆grencilerinin Akıllı Telefon Bagı̆mlılık Düzeylerinin Belirlenmesi (Uzmanlık Tezi, Sağlı Bakanlığı Yıldırım Beyazıt Universitesi, Tıp Fakültesi Aile Hekimliği Anabilim Dalı, Ankara).

We Are Social. (2020). Digital in 2020. https://wearesocial.com/digital-2020.

Yalçın, C., Demirel, M., Harmandar Demirel, D., \& Çolakoğlu, T. (2017). Beden Eğitimi ve Spor Yüksekokulu Öğrencilerinin Boş Zamanın Anlamı İle Akıllı Telefon Bağımlılıklarına İlişkin Görüşlerinin İncelenmesi. İstanbul Üniversitesi Spor Bilimleri Dergisi, 7(1), 1-11. Retrieved from https://dergipark.org.tr/tr/pub/iuspor/issue/31010/323285

Yılmaz, G., Şar, A. H., \& Civan, S. (2015). Investigation of adolescent mobile phone addiction by socialanxiety effect of somevariable. Online Journal of Technology Addiction and Cyberbullying, 2(2), 20-37.

\section{Copyright Disclaimer}

Copyright for this article is retained by the author(s), with first publication rights granted to the journal.

This is an open-access article distributed under the terms and conditions of the Creative Commons Attribution license (http://creativecommons.org/licenses/by/3.0/). 